\title{
Senmetastaser til glandula thyreoidea fra nyrekarsinom
}

\begin{abstract}
BAKGRUNN Metastaser fra nyrecellekarsinomer til glandula thyreoidea er uvanlig og det kliniske forløpet ofte langtrukkent. Vi ønsket å kartlegge forekomsten av slike metastaser i kirurgisk biopsimateriale ved to norske sykehus.
\end{abstract}

MATERIALE OG METODE Diagnosearkivene ved Avdeling for patologi ved Nordlandssykehuset Bodø (perioden 2002-11) og ved Avdeling for Patologi og medisinsk genetikk ved St. Olavs hospital (perioden 1986-2011) ble gjennoms økt for mulige metastaser fra nyrecellekarsinom til glandula thyreoidea. Biopsiremisser og kliniske journaler ble senere gjennomgått for å kartlegge kjønn, alder, symptomer, preoperative undersøkelser, tumorstørrelse, immunprofil og behandling samt videre klinisk forløp og overlevelse.

RESULTATER Biopsimateriale fra fem pasienter, fire kvinner og en mann, i alderen 58-89 år viste metastaser i glandula thyreoidea som morfologisk og immunhistokjemisk var identiske med nyrecellekarsinomene som tidligere var fjernet fra disse pasientene. Det var gått lang tid, opptil 25 år (median 21 år) før metastasene viste seg og ga kliniske symptomer. Alle pasientene ble operert. Overlevelsen etter hemityreoidektomi varierte fra to måneder til 13 år. Én pasient var fremdeles i live da materialet ble gjennomgått.

FORTOLKNING Metastaser fra klarcellet nyrecellekarsinom til glandula thyreoidea kan opptre mange år etter at primærtumoren er fjernet og gi kliniske symptomer som ved knutestruma. Dersom det ikke finnes andre metastaser, er kirurgisk behandling indisert. Prognosen er god hos enkelte pasienter.

Metastaser i glandula thyreoidea som gir kliniske symptomer er sjeldne, de utgjør omkring $2-3 \%$ av alle maligne svulster i kjertelen i kirurgisk biopsimateriale (1). Forekomsten av metastaser i autopsimaterialer ved kreftdødsfall kan være langt høyere, opptil $24 \%(2,3)$. Dette dreier seg imidlertid om metastaser påvist ved mikroskopisk undersøkelse, de spiller derfor klinisk ingen rolle.

Sekundærsvulster i glandula thyreoidea kan være spredning fra melanomer, sarkomer eller karsinomer (særlig fra mamma, lunge, nyre eller gastrointestinaltractus) (4). Svulstene kan opptre som isolerte knuter eller som en diffus struma, noen ganger samtidig med metastaser i andre organer (5). Den vanligste tumormetastasen som klinisk kan forveksles med en primærtumor i glandula thyreoidea er imidlertid nyrecellekarsinom, som også kan vise seg først mange år etter at nyretumoren er fjernet (4-6).

Vi ønsket å gjennomgå funn av metastaser fra klarcellet nyrekarsinom i biopsimaterialet fra to sykehus og rapporterer her fem pasienter med metastaser fra nyrecellekarsinom til glandula thyreoidea. Metastasene ble først erkjent og operativt fjernet opptil 25 år etter at primærtumoren i nyren var fjernet.

\section{Materiale og metode}

Diagnosearkivene ved Avdeling for patologi ved Nordlandssykehuset Bodø og ved Avdeling for patologi og medisinsk genetikk ved St. Olavs hospital ble gjennomsøkt for å finne metastaser i glandula thyreoidea registrert i det kirurgiske biopsimaterialet. Ved databasene benyttes et felles kodeverk for norske patologiavdelinger (SNOMED), der alle organer (T-koder) og alle typer svulster blir registrert med femsifrede tallkoder (Mkoder). Alle metastaser har 6 som siste siffer i morfologikoden. Det ble ikke foretatt noen koblinger mot andre registre.

Ved St. Olavs hospital registrerte man også totalt antall thyreoideabiopsier i 25 -årsperioden og antall maligne svulster i glandula thyreoidea. Det ble også registrert latenstid fra fjerning av primærtumor til operativ behandling av metastasene. Fra biopsiremissene registrerte man størrelse og lokalisering av primærtumor og av metastasene.

Arkivert tumormateriale fra primærtumor i nyrene og fra metastasene ble fremskaffet og diagnosen mikroskopisk bekreftet. Ved metastaser fra andre typer svulster ble det ikke foretatt systematisk mikroskopisk revisjon. Det ble foretatt Fuhrman-gradering av nyresvulstene (7) og supplerende immunhistokjemiske undersøkelser av parafinsnitt i de tilfellene der dette ikke tidligere var utført for å sammenlikne immunprofilene i primærtumoren og metastasene. Antistoffer mot følgende epitoper ble benyttet: CD10, vimentin, tyreoglobulin og thyreoideatransskripsjonsfaktor 1 (TTF-1). For å vurdere proliferasjonsaktiviteten ble snitt fra primærtumor og metastaser også farget med antistoff mot Ki67 (Mib1) og 500 cellekjer-

\author{
Anne Lise Villumsen \\ Patologisk anatomisk laboratorium \\ Kjersti Mevik \\ Kirurgisk avdeling \\ Nordlandssykehuset Bodø
}

\section{Hans E. Fjøsne}

Kirurgisk klinikk

\section{Marianne B. Brekke}

Avdeling for patologi og medisinsk genetikk

St. Olavs hospital

\section{Olav A. Haugen}

olav.haugen@ntnu.no

Institutt for laboratoriemedisin,

kvinne- og barnesykdommer

Norges teknisk-naturvitenskapelige universitet

Engelsk oversettelse på www.tidsskriftet.no

\section{HOVEDBUDSKAP}

Metastaser fra nyrecellekarsinom til glandula thyreoidea kan oppstå flere år etter at svulsten i nyren er fjernet.

Kirurgisk fjerning av metastase til glandula thyreoidea kan $\mathrm{i}$ isolerte tilfeller gi langvarig overlevelse. 
ner vurdert av samme patolog i hvert tilfelle. Alle fargingene ble utført med fargemaskin (DAKO* Autostainer Link 48) og med antistoffer som brukes i rutinediagnostikken.

Biopsiremisser og kliniske journaler fra pasienter med metastaser fra nyrecellekarsinom ble gjennomgått for å kartlegge kjønn, alder, symptomer, preoperative undersøkelser, tumorstørrelse, immunprofil og behandling samt videre klinisk forløp og overlevelse.

Samtykke til publisering av kasuistikkene ble innhentet fra de aktuelle pasienter som fortsatt var i live og fra pårørende til de avdøde. Personvernombudene ved Nordlandssykehuset og St. Olavs hospital har godkjent prosjektet.

\section{Resultater}

Ved St. Olavs hospital ble det i perioden 1986-2011 undersøkt i alt 3930 biopsier fra glandula thyreoidea. Av disse var det 433 maligne svulster $(11 \%)$. I alt ni av disse $(2,1 \%)$ var metastaser, hvorav seks var fra lunge, tykktarm eller mamma og tre var metastaser fra klarcellet nyrecellekarsinom. Ved Nordlandssykehuset ble det i perioden 2002-11 registrert to metastaser i glandula thyreoidea som begge var klarcellet, forenlig med metastase fra nyrecellekarsinom.

Pasientene var fire kvinner og en mann i alderen 58-89 år. Nyretumoren var blitt fjernet ved total nefrektomi 6-25 år tidligere (tab 1). Primærsvulstene var relativt store, med største diameter 5-9 cm. Det ble ikke hos noen påvist tegn til gjennomvekst av nyrekapselen eller innvekst i nyrebekkenslimhinnen eller i sentrale vener. I ett tilfelle ble det påvist tumorceller i venyler. En av svulstene var delvis cystisk. Mikroskopisk forelå det i alle tilfellene et klarcellet karsinom, Fuhrman-gradering 1-3. Proliferasjonsraten, bedømt ut fra andel Ki67positive celler ( \%) i nyresvulstene var gjennomgående meget lav. Andelen varierte fra $<1 \%$ til $5 \%(\operatorname{tab} 2)$.

Hos fire av pasientene viste tumor seg på halsen som en ensidig hevelse i glandula thyreoidea som utviklet seg i løpet av måneder 6-25 år etter fjerning av primærtumor i nyren. En av pasientene hadde hatt knutestruma i mange år, og man mistenkte metastase da glandula thyreoidea vokste ytterligere. I dette tilfellet forelå det kompresjon av trachea.

Preoperativt ble det $\mathrm{i}$ to tilfeller utført finnålspunksjon, som viste maligne celler forenlig med metastaser fra klarcellet karsinom. I ett tilfelle ble det også utført nålebiopsi, som viste klarcellet karsinom med immunhistokjemisk profil som passet med metastasen. Alle pasientene ble operert med hemityreoidektomi. Overlevelsen etter operasjon varierte fra to måneder til 13 år, og en av pasientene var fremdeles i live da data ble gjort opp.

Tabell 1 Pasientpopulasjon med metastaser fra nyrecellekarsinom til glandula thyreoidea $(\mathrm{N}=5)$. Alder ved tidspunktet for thyreoideaoperasjonen er angitt

\begin{tabular}{lr}
\hline Kjønnsfordeling (kvinne : mann) & $4: 1$ \\
Median alder lår) (spredning) & $84(58-89)$ \\
Median latenstid (år) (spredning) & $21(6-25)$ \\
Median overlevelse etter operasjon (md.) (spredning) & $14(2-156)^{1}$ \\
\hline
\end{tabular}

1 En pasient var i live da materialet ble gjennomgått

Tabell 2 Størrelse (cm) på nyretumor og metastasene i glandula thyreoidea med Fuhrmanngradering (fra 1 til 4) og Ki67-aktivitet (\%) hos fem pasienter behandlet med hemityreoidektomi

\begin{tabular}{|c|c|c|c|c|c|c|}
\hline \multirow[b]{2}{*}{ Pasient } & \multicolumn{3}{|c|}{ Nyretumor } & \multicolumn{3}{|c|}{ Metastase } \\
\hline & Størrelse & Gradering & Ki67 & Størrelse & Gradering & Ki67 \\
\hline 1 & 5 & 2 & 5,1 & 10,0 & 3 & 14,2 \\
\hline 2 & 6 & 2 & $<1$ & 2,5 & 3 & 8,2 \\
\hline 3 & 6 & 3 & 4,0 & 9,5 & 4 & 50,0 \\
\hline 4 & 7 & 1 & $<1$ & 7,0 & 3 & 14,3 \\
\hline 5 & 9 & 1 & $<1$ & 4,6 & 3 & 4,0 \\
\hline
\end{tabular}

Metastasene ble i tre tilfeller påvist i høyre thyreoidealapp, i to tilfeller i venstre lapp. Svulstene varierte i størrelse fra $2,5 \mathrm{~cm}$ til $10,0 \mathrm{~cm}$ i største diameter og var i ett tilfelle mer diffust infiltrerende. De inntok mesteparten av lapperesektatene, og stedvis var det bare rester av bevart thyreoideavev. Mikroskopisk viste samtlige svulster en relativt ensartet oppbygning, med dominans av store celler med lyst, hovedsakelig vannklart cytoplasma og litt varierende kjernestørrelse som et klarcellet karsinom.

Immunhistokjemisk undersøkelse viste at metastasene var negative for tyreoglobulin og TTF-1, men positive for vimentin og CD10, som i de primære nyresvulstene (fig 1). Andelen Ki67-positive celler var vesentlig høyere i alle metastasene enn i de respektive nyresvulstene ( $\operatorname{tab} 2$ ).

En av pasientene fikk påvist en metastase $\mathrm{i}$ overarmen før metastasen i glandula thyreoidea ble funnet. Hos en annen pasient ble det etter hemityreoidektomi påvist karsinomutvikling i gjenværende nyre, over ti år etter første nefrektomi. Hos de øvrige pasientene ble det ikke påvist andre tumormetastaser, men obduksjon ble ikke utført i noen av tilfellene og dødsårsaken er ikke kjent.

\section{Diskusjon}

I det kirurgiske biopsimaterialet fra St. Olavs hospital ble det i perioden 1986-2011 diagnostisert $i$ alt 433 maligne svulster i glandula thyreoidea. Av disse var det ni metastaser $(2,1 \%)$, hvorav tre var spredning fra klarcellet nyrecellekarsinom. Dette er i god overensstemmelse med det som er rapportert i flere andre kliniske materialer $(1,8)$. En gjennomgang av studier fra de siste ti år har vist at nyrecellekarsinomer utgjør $48 \%$ av metastasene, fulgt av kolorektalkarsinomer $(10,4 \%)$, lungekarsinomer $(8,3 \%)$, mammakarsinomer (7,8\%) og sarkomer (4\%) (4).

Opptil 30-40\% av dem med nyrecellekarsinom har metastaser på diagnosetidspunktet, mens de fleste senere metastaser viser seg i løpet av 3-5 år $(9,10)$. Gjennomsnittlig går det ni år etter nefrektomien for metastasen i glandula thyreoidea manifesterer seg $(6,11)$, men det kan gå opptil 25 år, som to av våre tilfeller viser. Tidligere er det rapportert at det hos en pasient tok 26 år før metastasen ble klinisk erkjent (5). Det kan også opptre metastaser i andre organer, som hos to av våre pasienter. Heffess og medarbeidere (6) rapporterte fra et 40-års arkivmateriale at hos 13 av deres 36 pasienter med nyrekreft var metastasen i glandula thyreoidea det første tegn til malign nyrelidelse. 11 av pasientene ble deretter nefrektomert. Andre rapporter viser også at metastasen kan være en tidlig klinisk manifestasjon av nyrekreft $(1,12)$.

Diagnosen ble hos våre pasienter verifisert med gjennomgang av histologisk og immunhistokjemisk undersøkelse. Morfologisk kan det være vanskelig med sikkerhet å skille metastasene fra andre svulster i glandula thyreoidea, som også kan ha et sterkt innslag av «klare celler» og fremstå som et 

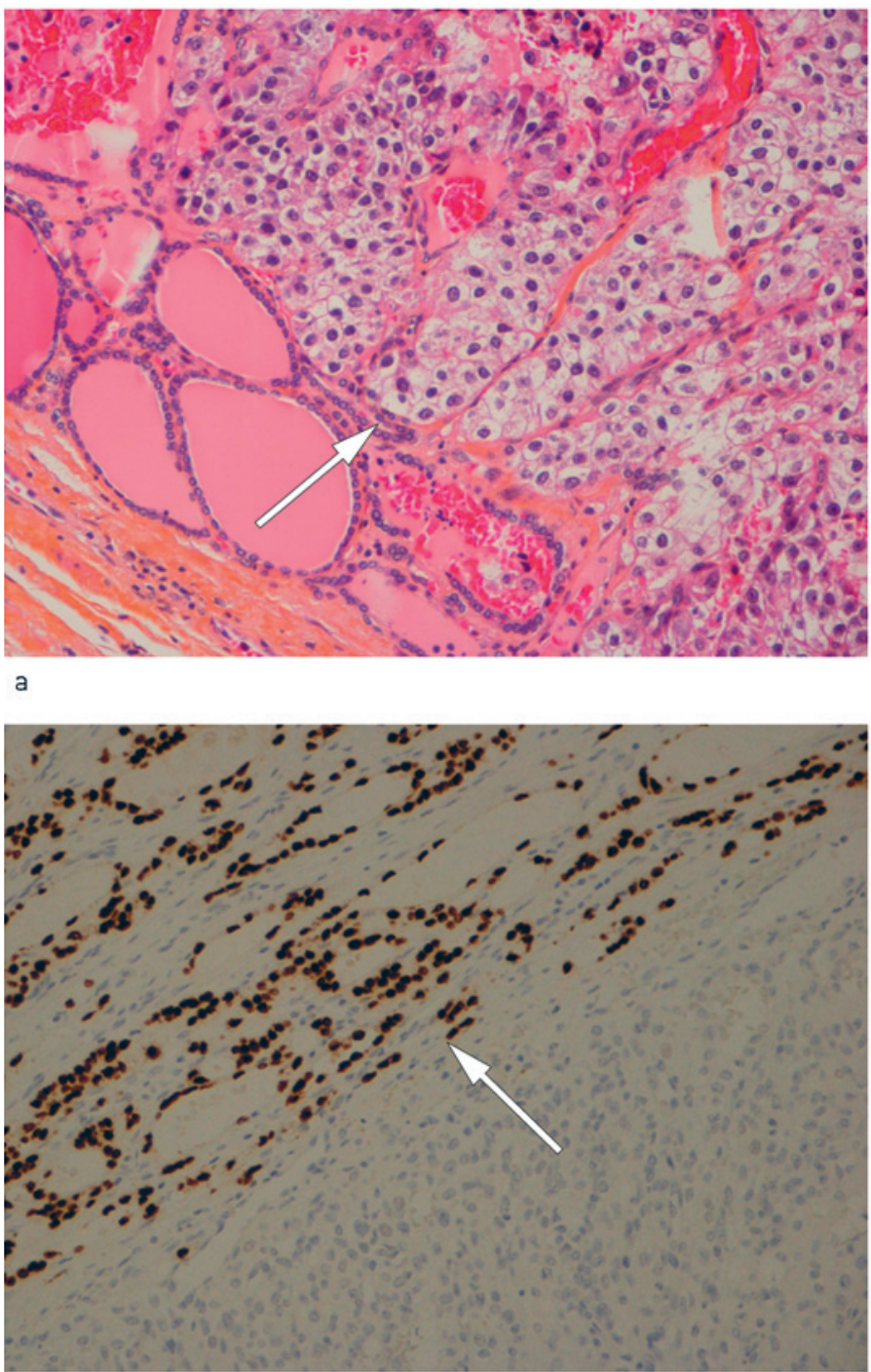

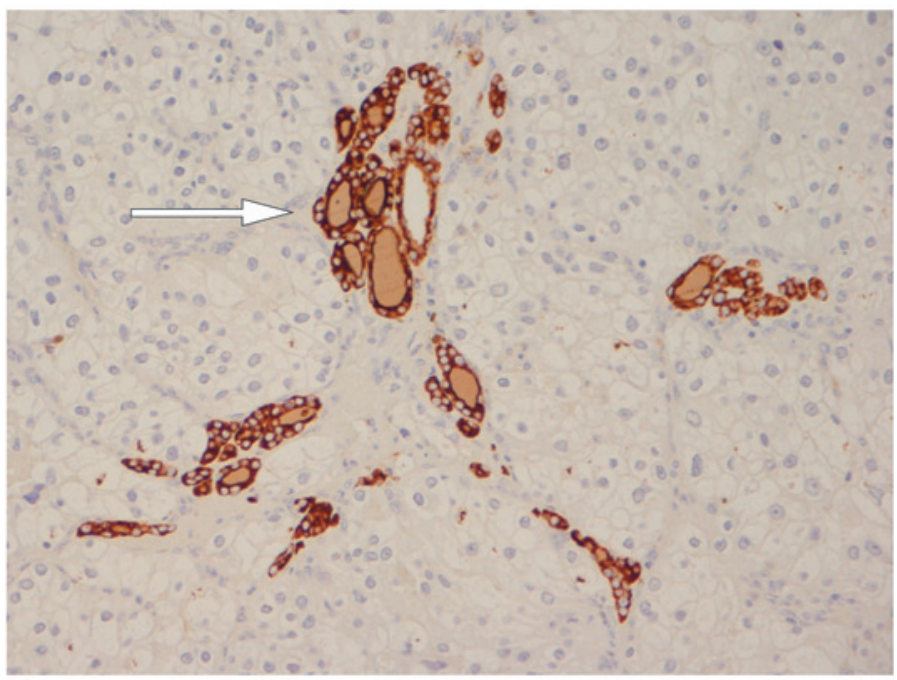

b

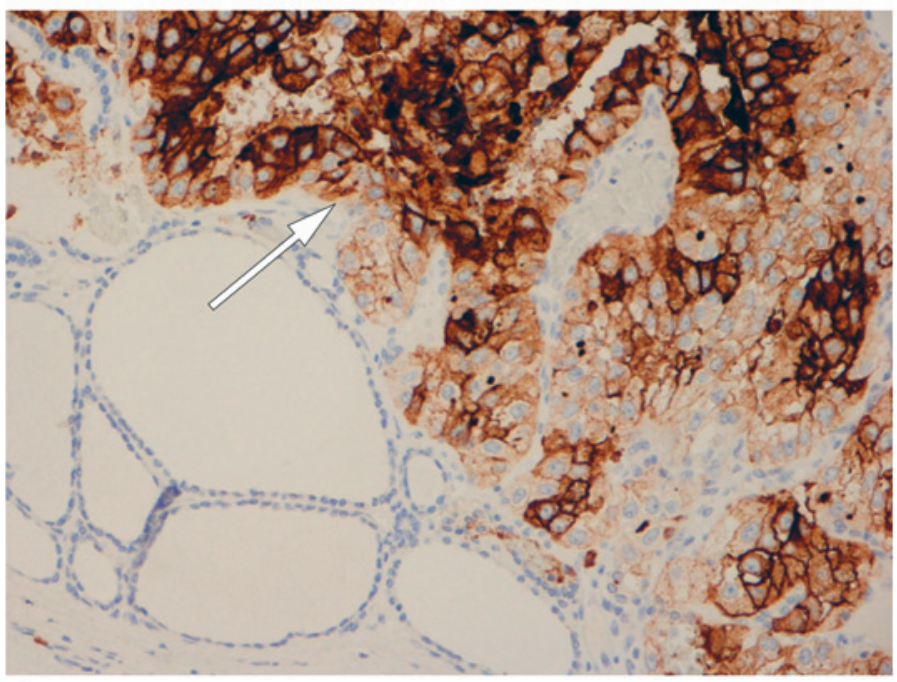

Figur 1 Metastase fra nyrecellekarsinom avgrenset mot normale thyreoideafollikler. a) Hematoksylin-eosin-safran-farget snitt. Pil markerer metastase. b) Immunhistokjemi rettet mot tyreoglobulin (normalt thyreoideavev markert med pil). c) Immunhistokjemi rettet mot thyreoideatranskripsjonsfaktor 1 (TTF-1) (normalt thyreoideavev markert med pill. d) Immunhistokjemi rettet mot cellemarkøren CD10 i tumor (tumorvev markert med pil)

hypernefrom (13), men immunhistokjemisk undersøkelse avklarte dette (1). Alle pasientene hadde klarcellet tumorvev med negativ reaksjon for tyreoglobulin og TTF-1.

Ki67 har i noen undersøkelser vist seg å være en uavhengig prognostisk markør ved nyrecellekarsinom (14-16), men den er vanskelig å bruke i rutinediagnostikken, siden den ofte viser meget lav andel av tumorceller i vekstfase (17). Dette var også tilfellet $\mathrm{i}$ tre av fem av nyrebiopsiene i denne undersøkelsen. Kombinasjon av lav Fuhrman-gradering og lav Ki67- fraksjon i primærtumor kan tyde på at metastasene i disse tilfellene initialt vokser langsomt. Høyere Ki67-fraksjon og høyere Fuhrman-gradering i metastasene kan passe med økt celleproliferasjon når de manifesterer seg klinisk etter mange år.
Det er høyst uklart hvilke forhold som spiller inn og som eventuelt hemmer videre tumorutvikling i maligne celler utgått fra primærtumor. Hadfield (18) introduserte begrepet «the dormant cancer cell» og mente at mitosehemming kunne være en følge av anoksi. For metastaser i glandula thyreoidea har det dessuten vært spekulert i mulig effekt av lokale hormonelle faktorer og høyt innhold av jod i vevet når det gjelder cellenes vekstmuligheter (11). Metastaseutvikling skjer trolig i et komplisert samspill mellom genetiske faktorer i tumorcellene, mikromiljøet i ulike vevstyper og genetiske faktorer hos bæreren (19).

Pasientene er gjerne eldre, 60-80 år, og det er en lett overvekt av kvinner $(11,20)$, noe som også var tilfellet $\mathrm{i}$ vårt materiale. Metastasen var en solitær knute eller med- førte diffus forstørring av kjertelen. Det var ingen sidepreferanse i materialet.

Det er i noen sjeldne tilfeller rapportert metastaser i en primærsvulst i thyreoidea («kollisjonstumor») (21). Bohn \& Gjørup (22) rapporterte det første skandinaviske tilfellet av metastase fra nyrekarsinom til thyreoidea. Pasienten var en mann som var behandlet i ti år for hypertyreose. Forfatterne hevdet at metastaser $\mathrm{i}$ glandula thyreoidea fortrinnsvis forekommer der det på forhånd er patologiske forandringer. Av våre pasienter hadde en av kvinnene hatt knutestruma i mange år, men materialet tillot for øvrig ingen vurdering av hvilke patologiske forandringer som ellers kunne være til stede. En litteraturstudie fra de siste ti årene (4) viste at $44,2 \%$ av metastasene faktisk forekom samtidig med kolloid struma, benigne 
neoplasmer eller tyreoiditt, og det ble foreslått at dette kunne forklares med endring i blodforsyningen med redusert oksygenering og jodinnhold.

Behandlingen av metastaser i glandula thyreoidea fra nyrekeft er kirurgisk og består $i$ enten partiell reseksjon eller total tyreoidektomi (8). Aktiv kirurgisk intervensjon er særlig aktuelt dersom det ikke foreligger tegn til spredning av tumor for øvrig (23), men palliative inngrep for å avlaste spesielle symptomer, for eksempel stridor, kan også være aktuelt $(1,24)$. Etter operasjon hadde pasientene i materialet en median overlevelse på 14 måneder. Et større europeisk materiale på 45 pasienter viste $51 \%$ femårsoverlevelse (25). Ved multivariat analyse var prognosen dårligst for pasienter over 70 år og for pasienter som hadde metastaser til gjenværende nyre. I en annen serie med metastaser fra forskjellige maligne svulster var median overlevelse 26 måneder (8). Ved partiell tyreoidektomi er det en ikke ubetydelig risiko for residiv (1) dersom tumoren ikke er helt avgrenset og reseksjonskantene sikkert fri.

Selv om metastaser til glandula thyreoidea ofte vil representere et terminalt fenomen og opptre sent i forløpet av en kreftsykdom, er det viktig å overveie muligheten for at isolerte tumorer i glandula thyreoidea hos pasienter med tidligere nyrekreft kan være metastaser som kan behandles kirurgisk med godt resultat.

Pasient/pårørende har gitt samtykke til at artikkelen blir publisert.

\section{Anne Lise Villumsen (f. 1981)}

er lege i spesialisering.

Forfatter har fylt ut ICMJE-skjemaet og oppgir ingen interessekonflikter.

\section{Kjersti Mevik (f. 1979)}

er lege i spesialisering.

Forfatter har fylt ut ICMJE-skjemaet og oppgir ingen interessekonflikter.

\section{Hans E. Fjøsne (f. 1948)}

er spesialist i kirurgi, dr.med., avdelingsoverlege og professor.

Forfatter har fylt ut ICMJE-skjemaet og oppgir ingen interessekonflikter.

\section{Marianne B. Brekke (f. 1969)}

er spesialist i patologi og overlege.

Forfatter har fylt ut ICMJE-skjemaet og oppgir ingen interessekonflikter.

\section{Olav A. Haugen (f. 1934)}

er spesialist i patologi, dr.med. og tidligere avdelingssjef , professor i patologi og senere i rettsmedisin ved Norges teknisk-naturvitenskapelige universitet. Som emeritus har han hatt overlegevikariater i patologi ved St. Olavs hospital og ved Nordlandssykehuset Bodø. Forfatter har fylt ut ICMJE-skjemaet og oppgir ingen interessekonflikter.

\section{Litteratur}

1. Wood K, Vini L, Harmer C. Metastases to the thyroid gland: the Royal Marsden experience. Eur J Surg Oncol 2004; 30: 583-8.

2. Berge T, Lundberg S. Cancer in Malmö 1958-1969. An autopsy study. Acta Pathol Microbiol Scand Suppl 1977; 260: 1-235.

3. Shimaoka K, Sokal JE, Pickren JW. Metastatic neoplasms in the thyroid gland. Pathological and clinical findings. Cancer 1962: 15: 557-65.

4. Chung AY, Tran TB, Brumund KT et al. Metastase to the thyroid: a review of the literature from the last decade. Thyroid 2012; 22: 258-68.

5. Nakhjavani MK, Gharib H, Goellner JR et al. Metastasis to the thyroid gland. A report of 43 cases. Cancer 1997; 79: 574-8.

6. Heffess CS, Wenig BM, Thompson LD. Metastatic renal cell carcinoma to the thyroid gland: a clinicopathologic study of 36 cases. Cancer 2002; 95 : 1869-78

7. Delahunt B. Advances and controversies in grading and staging of renal cell carcinoma. Mod Pathol 2009; 22 (suppl 2): S24-36.

8. Nixon IJ, Whitcher M, Glick J et al. Surgical management of metastases to the thyroid gland. Ann Surg Oncol 2011; 18: 800-4

9. Griffin N, Gore ME, Sohaib SA. Imaging in metastatic renal cell carcinoma. AJR Am J Roentgenol 2007: 189: $360-70$.

10. Mills EJ, Rachlis B, O'Regan C et al. Metastatic renal cell cancer treatments: an indirect comparison meta-analysis. BMC Cancer 2009; 9: 34

11. Sindoni A, Rizzo M. Tuccari $G$ et al. Thyroid metastases from renal cell carcinoma: review of the literature. ScientificWorld Journal 2010; 10: $590-602$.

12. Benoit L, Favoulet P, Arnould L et al. Les metastases intrathyroidiennes du cancer du rein a cellules claires: presentation de sept cas et revue de la litterature. Ann Chir 2003; 129: 218-23.

13. Rosai J, Tallini G. The thyroid gland. I: Rosai J, red. Rosai and Ackerman's Surgical Pathology. Bd. 1. 10. utg. Edinburgh: Mosby, 2011: 487-564

14. de Riese WT, Crabtree WN, Allhoff EP et al. Prognostic significance of $\mathrm{Ki}-67$ immunostaining in nonmetastatic renal cell carcinoma. J Clin Oncol 1993; 11: 1804-8.

15. Kankuri M, Söderström KO, Pelliniemi TT et al. The association of immunoreactive p53 and Ki-67 with T-stage, grade, occurrence of metastases and survival in renal cell carcinoma. Anticancer Res 2006: 26: 3825-33.

16. Kroeze SG, Bijenhof AM, Bosch JL et al. Diagnostic and prognostic tissuemarkers in clear cell and papillary renal cell carcinoma. Cancer Biomark 2010; 7: 261-8.

17. Dudderidge TJ, Stoeber K, Loddo M et al. Mcm2, Geminin, and KI67 define proliferative state and are prognostic markers in renal cell carcinoma. Clin Cancer Res 2005; 11: 2510-7.
18. Hadfield G. The dormant cancer cell. BMJ 1954; 2: $607-10$

19. Wikman H, Vessella R, Pantel K. Cancer micrometastasis and tumour dormancy. APMIS 2008; 116: $754-70$

20. Green LK, Ro JY, Mackay B et al. Renal cell carcinoma metastatic to the thyroid. Cancer 1989; 63: $1810-5$

21. Stevens TM, Richards AT, Bewtra $C$ et al. Tumors metastatic to thyroid neoplasms: a case report and review of the literature. Patholog Res Int 2011. doi: 10.4061/2011/238693.

22. Bohn CS, Gjørup PA. Metastasis from a hypernephroma of the thyroid gland. Acta Pathol Microbio Scand 1954; 35: 321-8.

23. Mirallié E, Rigaud J, Mathonnet M et al. Management and prognosis of metastases to the thyroid gland. J Am Coll Surg 2005; 200: 203-7.

24. Palazzo FF, Bradpiece HA, Morgan MW. Renal cell carcinoma metastasizing to the thyroid gland. Scand J Urol Nephrol 1999: 33: 202-4.

25. lesalnieks I, Winter H, Bareck E et al. Thyroid metastases of renal cell carcinoma: clinical course in 45 patients undergoing surgery. Assessment of factors affecting patients' survival. Thyroid 2008; 18: 615-24.

Mottatt 6.8. 2012, første revisjon innsendt 11.11. 2012, godkjent 19.8. 2013. Redaktør Kristin Viste. 